\title{
THE ROLE OF SUCCESSOR IN CAPITAL ACCUMULATION \\ IN POLISH FAMILY FARMS
}

\section{PĒCNĀCĒJA LOMA KAPITĀLA UZKRĀŠANĀ POL̦U ĢIMEN̦U LAUKU SAIMNIECĪBĀS}

Joanna Bereżnicka

PhD, Faculty of Economic Sciences in Warsaw University of Life Sciences

E-mail: joanna_bereznicka@sggw.pl,

Poland

\begin{abstract}
The aim of this work was to study the behaviour of farmers both with and without successors, within the scope of achieving economic profits and investment implementation. It was acknowledged that these two elements are the markers of capital accumulation in family farms. The research was conducted between the years 2004-2011 on a group of farmers aged over 50. Logit models showed that having a successor did not prejudge the ability to make an economic profit, but did however influence the farms' investment level.
\end{abstract}

Keywords: economic profit, family farm, investments, successor.

JEL code: $D 92$

\section{Introduction}

The successor phenomenon is characteristic of many family firms, including farms in Poland. Studies concerning family farm inheritance can be found in literature within the scope of village sociology (Friedberger 1983; Carroll \& Salamon 1988). However, according to (Mishra, El-Osta, Johnson, 2004) agricultural economists have not paid too much attention to this issue. In Poland, there is one piece of work which concerns the theme of family farm succession (Klank, 2006). Pieces of work which refer to the problem of inheritance mainly focus on the influence of succession on tax burdens (Harl 1989; Harlin 1992) or present the context of succession planning and their decisive factors (Mishra i in, 2010). M. Simeone (2005) concentrates on the reasons for the resignation of the younger generation from work in the agricultural sector. In her studies, profit models showed that low levels of income were not conducive to remaining in this sector. Thus, the problem of no successor may be a result of the desire to achieve higher earnings from sources other than that of the family farm. In addition, there is a high variability of farming product prices in Poland. The lack of a successor may contribute to the fall of the farm. As Weiss (1999) has shown in his studies on Austrian farms, family succession had a positive influence on the survival of the farm. Thus, literature indicates a positive effect of the succession of farms by the younger family generation. However, there is 
no unequivocal research into whether farmers with successors behave differently within the scope of investment and increasing resources in comparison with those farmers with no perspective of transferring the farm to the next generation. Increasing the size of land resources in family farms is limited. Capital can be increased financially - in the shape of economic profit and real investment.

\section{Aim and methodology of studies}

The aim of this work was to verify if having a successor in a farm caused an increase in its estate and acted as a factor giving potentially higher possibilities to accumulate financial capital. A hypothesis was formulated stating that farms with successors achieve better economic results and make far more investments to ensure better "starting" conditions for the younger generation. The following tasks were carried out in this study:

1. Analysis of the farms' factor endowments;

2. An assessment of the achieved production, income and investment level.

Farms which constituted the basis for conducting the analysis ran accounting records within the scope of FADN PL between the years 20042011. There were 2405 such entities, however to achieve the established aim a group of farmers aged at least 50 were selected in the first year of the analysis. It was acknowledged that farmers at such an age are able to indicate if there is a possibility for succession or not. Taking the above mentioned facts into account, 259 farms remained for further analysis. The studies were conducted between the years 2004-2011 and involved the same farms. This enabled the analysis of farmer behaviour, for example within the scope of investments made, for a period of 7 years. After the group selection, it occurred that 185 farms had successors and 74 were without. This shows that there still is a strong patrimonial bond in Polish agriculture. On the other hand, this may be the effect of an inability to utilize the work force away from agriculture. The lack of a successor may be the effect of relatively low levels of income achieved by the farm, which discourages younger workers from working as farmers. The first criterion of the assessment was to verify if farms with successors achieve better economic results. This was calculated on the basis of their ability to achieve a positive level of economic profit, denoted (ZE). The following formula was used:

$$
\mathrm{ZE}=\mathrm{DRGR}-\mathrm{Ka}
$$

where: DRGR - Income of family farm;

$\mathrm{Ka}$ - Alternative costs of own factors of production. 
It was acknowledged that information concerning the level of income from family farms is insufficient. This was because the family farm was connected with the household. Thus, it is impossible to calculate if running the family farm alone is enough to pay for all factors of production and to generate a financial surplus - savings.

The second criterion for the assessment of farmer behaviour was the level and types of investments. It seems that those farmers, who take the succession of their farm into consideration, should pay more attention to increasing the surface area as well as real investments in machines and equipment.

To check the dependency between having a successor and the obtained economic results, Spearman's rank correlation analysis was carried out. Owing to the fact that the "successor" was of a qualitative character, two values were assumed - "1" successor "2" lack of successor. To define the significance of the difference between the groups within the scope of factor endowment - nonparametric Kolmogorov-Smirnov tests were used. To establish the influence of having a successor on investments made and the achievement of economic profit, logistic regression models were developed:

$$
\operatorname{logit}(\mathrm{p})=\log \left(\frac{p}{1-p}\right)=x^{\prime} \beta=\beta_{0}+\beta_{1} x_{1}+\ldots+\beta_{k} x_{k}
$$

where: $x^{\prime}=\left(1, x_{1}, x_{2}, \ldots, x_{k}\right)^{\prime}$ is a vector of exogenous variables;

$\beta=\left(\beta_{0}, \beta_{1}, \ldots . \beta_{k}\right)^{\prime}-$ is a vector of parameters;

The parameters in the model were estimated using the maximum likelihood method.

\section{Results of the research}

Table 1 presents numerical data concerning factor endowment in the groups of farms both with and without a successor.

The resources of land in the groups selected were similar in size (approximately $30 \mathrm{ha}$ ), which in the conditions of Polish family agriculture exceeds the average surface area of farms in Poland threefold. This proves that the farms participating in data collection for the needs of the FADN are representative of those which produce for market purposes. Changes in the average size of the surface area of agricultural land were slow, though it is worth paying attention to the fact that in the group with successors one can observe a constant tendency in the increase of the surface area, whereas in the group without, there were fluctuations and the tendency was a decreasing one. This may indicate that farmers without a successor were not interested in increasing the 
basic resource in agriculture. Such behaviour caused a lower involvement of people who work on the farm. This is proven by a fall in AWU from 2 in 2005-2006 to 1.7 in the final years of the analysis. In the same period a fall can also be observed in AWU for the group with a successor, however 2 "full time" adult worker units were on those farms. As far as capital is concerned, the group with successors observed a consistent increase in the value of assets (without land value) which meant that the farmers from this group invested in tangible fixed assets and implemented widened reproduction, which could indicate that farmers aimed to improve utilities for the younger generation. However, in the group without a successor, there were fluctuations within the scope of the capital value. Though its average value in the final year was higher than that of 2004, the difference of 4 thousand PLN in nominal value did not give an increase of capital in real terms. In the group with successors an almost twofold increase in the value of the estate was observed. These changes were the result of higher economic results. However, was this reflected in the results obtained? To confirm the difference of the groups in factor endowments, a nonparametric Kolmogorov-Smirnov test was carried out, whose results are found in table 2 .

Table 1.

Amount of land, labour and capital in groups of farms in the years 2004-2011

(author's calculations based on FADN PL)

\begin{tabular}{|c|c|c|c|c|c|c|}
\hline \multirow{2}{*}{ Year } & \multicolumn{2}{|c|}{ Land [ha] } & \multicolumn{2}{c|}{ Labour [AWU1] } & \multicolumn{2}{c|}{$\begin{array}{c}\text { Capital (assets) } \\
\text { [thousands of. PLN] }\end{array}$} \\
\cline { 2 - 7 } & with & Without & with & without & with & without \\
\hline 2004 & 29,5 & 30,1 & 2,2 & 1,9 & 390 & 292 \\
\hline 2005 & 30,3 & 30,3 & 2,1 & 2,0 & 390 & 291 \\
\hline 2006 & 31,1 & 29,6 & 2,2 & 2,0 & 416 & 287 \\
\hline 2007 & 31,8 & 30,1 & 2,1 & 1,9 & 444 & 294 \\
\hline 2008 & 32,8 & 29,2 & 2,0 & 1,8 & 467 & 296 \\
\hline 2009 & 33,3 & 30,5 & 2,0 & 1,7 & 483 & 292 \\
\hline 2010 & 33,5 & 28,1 & 2,0 & 1,7 & 496 & 288 \\
\hline 2011 & 33,9 & 28,1 & 2,0 & 1,7 & 535 & 296 \\
\hline
\end{tabular}

${ }^{1} \mathrm{AWU}$ expresses the annual work unit of people working on an agricultural holding $1 \mathrm{AWU}=$ 2200 hours of work annually. 
Table 2.

Factor endowment differences in the investigated groups of farms - the results of the Kolmogorov-Smirnov test (author's calculations)

\begin{tabular}{|c|c|c|c|c|c|c|c|c|c|}
\hline \multirow[t]{2}{*}{ Distinction } & \multirow{2}{*}{$\begin{array}{c}\text { Max } \\
\text { difference } \\
\text { in minus }\end{array}$} & \multirow[t]{2}{*}{$\begin{array}{c}\text { Max } \\
\text { difference } \\
\text { in plus }\end{array}$} & \multirow[t]{2}{*}{ p-value } & \multirow{2}{*}{\begin{tabular}{|c|} 
Average \\
With \\
\end{tabular}} & \multirow{2}{*}{\begin{tabular}{|l|}
$\begin{array}{c}\text { Average } \\
2\end{array}$ \\
Without \\
\end{tabular}} & \multirow{2}{*}{$\begin{array}{c}\begin{array}{c}\text { Standard } \\
\text { deviation }\end{array} \\
\text { With }\end{array}$} & $\mid \begin{array}{c}\text { Standard } \\
\text { deviation } \\
2\end{array}$ & N 1 & N 2 \\
\hline & & & & & & & Without & WithV & Vithout \\
\hline \multicolumn{10}{|c|}{2004} \\
\hline Work [AWU] & $-0,027027$ & 0,224324 & $p<.01$ & 2,2 & 1,9 & 0,7 & 0,9 & 185 & 74 \\
\hline Land [ha UR] & $-0,027027$ & $0,264865 p$ & $p<.005$ & 29,5 & 30,1 & 35,5 & 83,1 & 185 & 74 \\
\hline $\begin{array}{l}\text { lapital } \\
\text { [thousands. } \\
\text { PLN] }\end{array}$ & $-0,024324$ & $0,264865 p$ & $p<.005$ & 390460,1 & 292376,4 & 307845,2 & 292187,3 & 185 & 74 \\
\hline \multicolumn{10}{|c|}{2005} \\
\hline Work [AWU] & $-0,013514$ & $0,264865 p$ & $p<.005$ & 2,2 & 2,0 & 0,8 & 1,5 & 185 & 74 \\
\hline Land [ha UR] & $-0,027027$ & $0,270270 p$ & $p<.001$ & 30,3 & 30,3 & 35,6 & 84,0 & 185 & 74 \\
\hline $\begin{array}{l}\text { lapital } \\
\text { [thousands. } \\
\text { PLN] }\end{array}$ & $-0,029730$ & 0,237838 & $p<.01$ & 390034,3 & 291402,5 & 296159,7 & 290188,2 & 185 & 74 \\
\hline \multicolumn{10}{|c|}{2006} \\
\hline Work [AWU] & $-0,027027$ & $0,300000 p$ & $p<.001$ & 2,2 & 2,0 & 0,8 & 1,5 & 185 & 74 \\
\hline Land [ha UR] & $-0,027027$ & $0,272973 p$ & $p<.001$ & 31,1 & 29,6 & 35,7 & 83,1 & 185 & 74 \\
\hline $\begin{array}{l}\text { Capital } \\
\text { [thousands. } \\
\text { PLN] }\end{array}$ & $-0,024324$ & 0,294595 & $p<.001$ & 416008,1 & 287218,8 & 317840,6 & 276531,9 & 185 & 74 \\
\hline \multicolumn{10}{|c|}{2007} \\
\hline Work [AWU] & $-0,027027$ & $0,289189 p$ & $p<.001$ & 2,1 & 1,9 & 0,8 & 1,1 & 185 & 74 \\
\hline Land [ha UR] & $-0,032432$ & $0,297297 p$ & $p<.001$ & 31,8 & 30,1 & 35,9 & 83,5 & 185 & 74 \\
\hline $\begin{array}{l}\text { Capital } \\
\text { [thousands. } \\
\text { PLN] }\end{array}$ & $-0,013514$ & $0,297297 p$ & $p<.001$ & 443663,3 & 294416,1 & 360977,7 & 286271,7 & 185 & 74 \\
\hline \multicolumn{10}{|c|}{2008} \\
\hline Work [AWU] & $-0,018919$ & 0,194595 & $p<.05$ & 2,0 & 1,8 & 0,7 & 0,7 & 185 & 74 \\
\hline Land [ha UR] & $-0,037838$ & $0,305405 p$ & $p<.001$ & 32,9 & 29,2 & 37,5 & 82,2 & 185 & 74 \\
\hline $\begin{array}{l}\text { Capital } \\
\text { [thousands. } \\
\text { PLN] }\end{array}$ & $-0,008108$ & $0,305405 p$ & $p<.001$ & 467311,6 & 295540,5 & 394595,7 & 287005,9 & 185 & 74 \\
\hline \multicolumn{10}{|c|}{2009} \\
\hline Work [AWU] & $-0,005405$ & $0,221622 p$ & $p<.025$ & 2,0 & 1,7 & 0,8 & 0,7 & 185 & 74 \\
\hline Land [ha UR] & $-0,027027$ & $0,305405 p$ & $p<.001$ & 33,3 & 30,5 & 37,8 & 83,2 & 185 & 74 \\
\hline $\begin{array}{l}\text { Capital } \\
\text { [thousands. } \\
\text { PLN] }\end{array}$ & $-0,010811$ & $0,294595 p$ & $p<.001$ & 483421,8 & 292503,8 & 421912,4 & 283101,5 & 185 & 74 \\
\hline
\end{tabular}


Table 2 cont.

\begin{tabular}{|c|c|c|c|c|c|c|c|c|c|}
\hline \multicolumn{10}{|c|}{2010} \\
\hline Work [AWU] & 0,000000 & 0,175676 & $\mathrm{p}<.10$ & 2,0 & 1,7 & 0,8 & 0,7 & 185 & 74 \\
\hline Land [ha UR] & $-0,027027$ & 0,305405 & $p<.001$ & 33,5 & 28,1 & 38,2 & 65,2 & 185 & 74 \\
\hline $\begin{array}{l}\text { Capital } \\
\text { [thousands. } \\
\text { PLN] }\end{array}$ & 0,000000 & 0,297297 & $p<.001$ & 496178,7 & 288811,6 & 442724,9 & 276937,1 & 185 & 74 \\
\hline \multicolumn{10}{|c|}{2011} \\
\hline Work [AWU] & $\mid-0,010811$ & 0,183784 & $\mathrm{p}<.10$ & 2,0 & 1,7 & 0,9 & 1,0 & 185 & 74 \\
\hline Land [ha UR] & $-0,032432$ & 0,297297 & $p<.001$ & 33,9 & 28,1 & 39,2 & 65,1 & 185 & 74 \\
\hline $\begin{array}{l}\text { Capital } \\
\text { [thousands. } \\
\text { PLN] }\end{array}$ & 0,000000 & 0,318919 & $p<.001$ & 535908,0 & 296969,1 & 487862,5 & 299212,3 & 185 & 74 \\
\hline
\end{tabular}

The differences (written in italics) are significant at significance level $\mathrm{p}>0,05$

The obtained results confirmed the (statistically significant) difference of the selected groups of farms on account of factor endowment. Only in the years 2010-2011 did the farms fail to show statistically significant differences. However, these concerned only one factor: work. With reference to capital one could expect statistically significant differences; however it seemed that the differences in the surface area of agricultural land were not. The test verified this assumption. It is worth noting that the differences in factor endowment played a significant role in the achievement of productive and economic results.

Table 3.

Production, income from family farms and economic profit in groups of farms between the years 2004-2011 (thousands. PLN)

(author's calculations on the basis of FADN PL).

\begin{tabular}{|l|c|c|c|c|c|c|c|c|}
\hline \multirow{2}{*}{ Year } & \multicolumn{2}{|c|}{ Plant production } & \multicolumn{2}{c|}{ Animal production } & \multicolumn{2}{|c|}{ Income } & \multicolumn{2}{c|}{ Economic profit } \\
\cline { 2 - 9 } & With & Without & With & Without & With & Without & With & Without \\
\hline 2004 & 65 & 41 & 79 & 53 & 46 & 26 & 2 & -9 \\
\hline 2005 & 53 & 37 & 87 & 60 & 46 & 35 & 2 & $-0,2$ \\
\hline 2006 & 60 & 42 & 90 & 58 & 55 & 35 & 9 & -1 \\
\hline 2007 & 88 & 57 & 100 & 60 & 74 & 47 & 30 & 12 \\
\hline 2008 & 73 & 44 & 103 & 57 & 59 & 37 & 5 & -5 \\
\hline 2009 & 66 & 44 & 100 & 53 & 55 & 35 & $-0,1$ & -8 \\
\hline 2010 & 88 & 50 & 107 & 57 & 82 & 42 & 22 & $-3,0$ \\
\hline 2011 & 106 & 55 & 119 & 62 & 100 & 50 & 37 & 2 \\
\hline
\end{tabular}

There were differences between all the investigated parameters in the selected groups. Those farms with successors achieved a significantly 
high value of production with animal production dominating. However, the production structure was similar in both the analyzed groups and the share of animal production fluctuated between $53-60 \%$. It is worth noting that despite similar resources of land, the value of production in selected groups was varied. This could indicate a high level of efficiency from units of land surface or running the business without needing a large area of agricultural land (e.g. seed eating animals, battery farming, pigs etc.) Differences in production values resulted in the achievement of higher incomes from family farms with a successor. Similar tendencies were seen in both groups with regard to changes in the level of income. During the period of studies, a twofold increase was observed in the value of income in farms with a successor, whereas in those without, the growth amounted to $92 \%$. It is worth noting that 2005 was more favourable for farmers without a successor. This was because a significant increase in their average value of income was observed. This indicates that farmers from this group took better advantage of the accession of Poland to the structures of the European Union. This was a difficult period for polish farmers because the prices of agricultural products fell significantly. This drop particularly concerned crops and is confirmed in the production value of the studied groups of farms. On the other hand, a form of support was observed in direct farming subsidies which acted as a form of compensation for the fall in prices.

It was established that those farmers with successors achieved an approximately 35\% higher work efficiency in comparison with groups without successors. However, capital productivity amounted to 0.43 and 0.40 respectively (the average in the whole period of studies). Therefore, there were only negligible differences in the use of capital. This seems to suggest an unfavourable use of assets by farmers who increased their value excessively, disproportionately to the growth in the value of production.

The use of their own factors of production and the value of income from family farms was the cause of negative economic growth for farmers without successors. Only in 2007 and 2011 did farmers from this group manage to fully pay for the use of their own factors of production particularly that of labour. It is interesting that farms without successors had a $16 \%$ return on assets, whilst the other group's amounted to $15 \%$. This may indicate better cost management, especially fixed costs, smaller investments and their better use in the creation of income from the family farm. Farmers do not keep accounts such as the return on capital. They take the nominal value of income into consideration. In this context, the lack of appropriately high income may be a reason for the decrease in the amount of work time in the farm and obtaining employment away 
from the farm, which was observed in the analysis of the resources of production factors on the basis of the data in table 1 .

As can be seen in table 1, farmers increased the value of assets (estate). In table 4 one can find numerical data concerning the value and type of investment.

Table 4.

The overall size of investments with the share of main investment types in groups of farms during the research period (thousands. PLN) (author's calculation on the basis of FADN PL)

\begin{tabular}{|c|c|c|c|c|c|c|c|c|}
\hline \multirow{3}{*}{ Year } & \multirow{2}{*}{\multicolumn{2}{|c|}{$\begin{array}{c}\text { Capital } \\
\text { expenditures }\end{array}$}} & \multicolumn{6}{|c|}{ From which investments made in: } \\
\hline & & & \multicolumn{2}{|c|}{$\begin{array}{l}\text { Machines and } \\
\text { equipment }\end{array}$} & \multicolumn{2}{|c|}{$\begin{array}{c}\text { Building } \\
\text { investments }\end{array}$} & \multicolumn{2}{|c|}{ Animals } \\
\hline & With & Without & With & Without & With & Without & With & Without \\
\hline 2004 & 14,1 & 6,4 & 6,7 & 3,1 & 2,2 & 2,3 & 6,3 & 1,0 \\
\hline 2005 & 31,5 & 12,8 & 13,0 & 9,0 & 10,0 & 2,2 & 8,5 & 1,6 \\
\hline 2006 & 42,8 & 8,2 & 26,0 & 2,5 & 16,5 & 4,0 & 8,3 & 2,1 \\
\hline 2007 & 38,6 & 16,7 & 17,8 & 3,1 & 11,0 & 6,7 & 9,0 & 3,0 \\
\hline 2008 & 45,0 & 7,5 & 14,0 & 4,3 & 8,4 & 0,6 & 10,5 & 2,7 \\
\hline 2009 & 27,6 & 8,6 & 12,5 & 5,0 & 6,0 & 0,5 & 13,5 & 3,4 \\
\hline 2010 & 33,4 & 10,5 & 14,9 & 4,5 & 4,1 & 1,4 & 10,8 & 2,1 \\
\hline 2011 & 40,1 & 19,6 & 16,0 & 8,2 & 11,4 & 2,2 & 13,2 & 3,0 \\
\hline
\end{tabular}

The level of implemented investments varied in the studied groups. Groups with successors made higher investments. Their level (apart from 2004) fluctuated between 30-40 thousand PLN. In the group without successors, higher fluctuations and investments of a higher value (above 10 thousand PLN) were made when the market conditions for agricultural products were favourable. Accession into European structures in 2004 is not without significance. This can be proven by the relatively low level of capital expenditures in 2004, regardless of the group and their higher value in the following years. This was due to the activation of finances designated towards the modernization of farms within the scope of the rural development program.

Despite the differences in value, the structure of investments was similar in the investigated groups. Farmers mainly invested in machines and equipment. Between the years 2005-2007 investments were made in buildings. In 2008, a higher amount was designated for the purchase of animals. This approach indicates that having a successor did not play a decisive role in the scope of investment, and the main factor was the economic situation of farmers. In table 5, the rank Spearman correlation coefficient is used to check the strength of any dependencies between 
having a successor and factors of production, achieved economic results and the level of investment.

Table 5.

Spearman rank correlation coefficients between the successor variable and factors of production, results achieved and investments

(author's calculations on the basis of FADN PL.)

\begin{tabular}{|c|c|c|c|c|c|c|c|c|}
\hline \multirow{2}{*}{ Variables } & \multicolumn{8}{|c|}{ YEAR } \\
\hline & 2004 & 2005 & 2006 & 2007 & 2008 & 2009 & 2010 & 2011 \\
\hline $\begin{array}{l}\text { Amount of } \\
\text { work }\end{array}$ & $-0,205$ & $-0,248$ & $-0,259$ & $-0,233$ & $-0,161$ & $-0,156$ & $-0,173$ & $-0,146$ \\
\hline $\begin{array}{l}\text { Surface of } \\
\text { agricultural } \\
\text { land }\end{array}$ & $-0,189$ & $-0,200$ & $-0,212$ & $-0,225$ & $-0,225$ & $-0,214$ & $-0,220$ & $-0,215$ \\
\hline Assets & $-0,213$ & $-0,209$ & $-0,234$ & $-0,230$ & $-0,233$ & $-0,243$ & $-0,246$ & $-0,257$ \\
\hline $\begin{array}{l}\text { Animal } \\
\text { production }\end{array}$ & $-0,126$ & $-0,131$ & $-0,122$ & $-0,107$ & $-0,093$ & $-0,062$ & $-0,057$ & $-0,056$ \\
\hline $\begin{array}{l}\text { Plant } \\
\text { production }\end{array}$ & $-0,233$ & $-0,170$ & $-0,190$ & $-0,107$ & $-0,093$ & $-0,062$ & $-0,057$ & $-0,056$ \\
\hline $\begin{array}{l}\text { Income } \\
\text { from family } \\
\text { farm }\end{array}$ & $-0,201$ & $-0,195$ & $-0,168$ & $-0,144$ & $-0,101$ & $-0,124$ & $-0,170$ & $-0,207$ \\
\hline $\begin{array}{l}\text { Economic } \\
\text { profit }\end{array}$ & $-0,124$ & $-0,107$ & $-0,071$ & $-0,091$ & $-0,023$ & $-0,027$ & $-0,074$ & $-0,152$ \\
\hline Investment & $-0,219$ & $-0,186$ & $-0,203$ & $-0,158$ & $-0,176$ & $-0,177$ & $-0,089$ & $-0,166$ \\
\hline Successor* & 1,000 & 1,000 & 1,000 & 1,000 & 1,000 & 1,000 & 1,000 & 1,000 \\
\hline
\end{tabular}

The coefficients in (bold) are significant with $\mathrm{p}<0.05$

* If there was a successor the variable received 1 , in the case of no

successor -2 .

It was established that there was a statistically significant variability in the scope of factor endowment and having a successor. The lack of a successor caused a decrease in factor endowment. It is worth emphasizing that in the case of work, this dependency, despite the small value of coefficient $r$ (around $0.2-0.26$ ) underwent a fall in the first four years to the level of 0.14-0.17. This indicates weakening correlations between having a successor and the factor of labour. The opposite relation was observed with the assets variable - after each year, the rank correlation coefficient increased, which is proven by stronger (though still weak ${ }^{2}$ ) associations between the considered parameters. This may

\footnotetext{
${ }^{2}$ Aczel [2000, s.480] points to a strong correlation when the coefficient amounts to approximately 0.9, less strong for $r=0.7$ and weak when $r=0.3$. However, Sobczyk [1997, s. 208-209] states that the correlation between two features is unclear if $r<0.3$ and clear for $r>$ 0.5 .
} 
mean a greater and greater gap between the value of assets and having a successor

It was observed that those farms with a successor dynamically increased their capital whereas those without a successor managed to slightly increase its value. The dependencies between the surface areas of agricultural land were the most stable, though their dependency was also negative. This results from little opportunity of change within the scope of agricultural land. What is interesting is that a statistically significant dependency was observed between the income of the family farm in almost all years (with the exception of 2008 - a significant deterioration in economic conditions).

Table 6 presents the estimated parameters for the logit model for dependent variable (Y) economic profit 0-1

Table 6.

Logit model estimation results (author's calculations)

\begin{tabular}{|c|c|c|c|c|c|}
\hline \multicolumn{6}{|c|}{$\begin{array}{l}\text { Logit Estimation using } 2072 \text { observations } \\
\text { Dependent variable (Y): ZeO_1 } \\
\text { Standard mistakes Quasi-Maximum Likelihood }\end{array}$} \\
\hline Variable & Coefficient & $\begin{array}{c}\text { Standard } \\
\text { mistake }\end{array}$ & $Z$ & Pvalue & Significance \\
\hline const & $-5,89664$ & 0,386925 & $-15,2398$ & $<0,00001$ & $* * *$ \\
\hline Labour resource & 0,684100 & 0,134611 & 4,900 & $<0,00001$ & **** \\
\hline Labour efficiency & 0,000047 & 0,0000041 & 11,4600 & $<0,00001$ & $* * *$ \\
\hline Capital productivity & $-6,91157$ & 0,684364 & $-10,0993$ & $<0,00001$ & $* * *$ \\
\hline Investments_0_1 & 0,614528 & 0,155323 & 3,9565 & 0,00008 & $* * *$ \\
\hline Successor & $-0,121467$ & 0,167473 & $-0,7253$ & 0,46827 & \\
\hline ROA & 30,9149 & 2,48156 & 12,4579 & $<0,00001$ & *** \\
\hline \multicolumn{6}{|c|}{ McFadden R-squared $=0,614515$} \\
\hline \multicolumn{6}{|c|}{ Corrected R-squared $=0,610241$} \\
\hline \multicolumn{6}{|c|}{ Log likelihood ratio $=-541,2450$} \\
\hline \multicolumn{6}{|c|}{ Number of 'correct predictions' $=1859(89,7 \%)$} \\
\hline \multicolumn{6}{|c|}{$\mathrm{f}($ beta' $\mathrm{x}$ ) to average independent variables $=0,492$} \\
\hline \multicolumn{6}{|c|}{ Likelihood quotient test: Chi-square(5) $=1725,63[0,0000]$} \\
\hline \multicolumn{6}{|c|}{$\begin{array}{l}* * * \text { Significant variable at } 0.1 \% \text { significance level } * \text { Significant variable at } \\
5 \% \text { significance level }\end{array}$} \\
\hline
\end{tabular}

Those variables which increased the probability of achieving an economic profit were: work efficiency, return on assets and investments. Greater labour resources were also a stimulant. This was probably due to the fact that farms with successors showed higher work resources and more frequently achieved positive economic profit.

The next model built for the investment dependent variable and results of its estimate presented in table 7. 
Results of logit model estimate (author's calculations)

\begin{tabular}{|c|c|c|c|c|c|}
\hline \multicolumn{6}{|c|}{$\begin{array}{l}\text { Logit estimate, using } 2072 \text { observations } \\
\text { Dependent variable (Y): investment_0_1 } \\
\text { Standard mistakes Quasi-Maximum Likelihood }\end{array}$} \\
\hline Variables & Coefficient & $\begin{array}{c}\text { Standard } \\
\text { mistakes }\end{array}$ & $Z$ & value $p$ & Significance \\
\hline const & $-1,07188$ & 0,171006 & $-6,2681$ & $<0,00001$ & $* * *$ \\
\hline Successor & 0,223373 & 0,109757 & $-2,0352$ & 0,04183 & $* *$ \\
\hline Labour resources & 0,363973 & 0,0849626 & 4,2839 & 0,00002 & $* * *$ \\
\hline Economic profit & 0,802593 & 0,11544 & 6,9525 & $<0,00001$ & $* * *$ \\
\hline Household & $-0,000011$ & $1,431 \mathrm{e}-06$ & $-8,2620$ & $<0,00001$ & $* * *$ \\
\hline Loans & 0,000024 & $3,44996 \mathrm{e}-06$ & 7,2292 & $<0,00001$ & $* * *$ \\
\hline Amortization & $-0,000012$ & 5,37093e-06 & $-2,4341$ & 0,01493 & $* *$ \\
\hline Assets & 0,000003 & $4,05705 \mathrm{e}-07$ & 8,0217 & $<0,00001$ & $* * *$ \\
\hline \multicolumn{6}{|c|}{ McFadden R-square $=0,134922$} \\
\hline \multicolumn{6}{|c|}{ Corrected R-square $=0,129309$} \\
\hline \multicolumn{6}{|c|}{ Log likelihood =-1233,027 } \\
\hline \multicolumn{6}{|c|}{ Akaike information criterion $=2482,05$} \\
\hline \multicolumn{6}{|c|}{ Number of 'correct predictions' = $1403(67,7 \%)$} \\
\hline \multicolumn{6}{|c|}{$\mathrm{f}(\mathrm{beta}$ 'x) to average independent variables $=0,497$} \\
\hline \multicolumn{6}{|c|}{ Likelihood quotient test: Chi-square(7) $=384,619[0,0000]$} \\
\hline
\end{tabular}

The following were factors which increased the likelihood of the implementation of investments in farms: assets, loans, labour resources, economic profit and having a successor. It is supposed that those farms with greater estates would be inclined to multiply them. This is of course possible when they achieve the appropriate financial resources and reach a sufficiently high income to enable covering alternative costs. Despite this, having a successor had no significance for achieving economic profit. These farms invested more frequently, at a higher level. Thus, they used the support of loans to finance the purchase of tangible assets. This was made possible by their financial condition. Households had a negative influence on the implementation of investments in the farm. This was because the household is competitive in relation to the farm. It, of course, seems that the family of the farmer which finances the needs of the farm would allow it to show greater potential for financing investments. However, what is more important is the tendency to make savings (investments) and real needs within this scope rather than the size of income. 


\section{Conclusion}

Family farms with successors possessed similar resources of land and labour. However, statistical analysis confirmed that these groups were statistically different with regard to factor endowments. This was reflected in the achieved production and economic results. Higher values of production and income from family farms were shown by the group in which there was a successor. However, production structure was similar in both of the analysed groups. Farmers without a successor failed to achieve a sufficiently high income to cover the costs of all factors of production involved in the running of the farm. This may have been caused by a lack of interest in the continuation of the farm by the next generation. Those farmers with successors were more interested in increasing resources of land (though its accessibility in Poland is low) and capital of approximately $40 \%$. This was the effect of investment. Farmers who did not have a successor also made investments albeit at a low level. This was confirmed by the rank Spearman correlation coefficient which showed a negative dependency between the successor variable and investments.

The building of logistics models did not confirm the influence of having a successor on the size of economic profit. However, the successor was a factor which increased the chances of real investments in farms. These results enabled the positive verification of the hypothesis concerning the implementation of significantly higher investments whose aim was to create a better start for the younger generation.

\section{Bibliography}

1. ACZEL, A.D. Statystyka w zarzadzaniu, Wydawnictwo Naukowe PWN, Warszawa 2000. 1000p.

2. CARROLL, E., SALAMON, S. Share and Share Alike: Inheritance Patterns in Two Illinois Farm Communities. Journal of Family History 13. 1988. P. 219-232

3. FRIEDBERGER, M. The Family Farm and the Inheritance Process: Evidence from the Corn Belt 1870-1950. Agricultural History 57, January 1983. P. 1-13

4. HARL, N. Current Estate Planning Topics. Journal of Agricultural Taxation and Law 11. Spring 1989. P. 74-85

5. HARLIN, J. The Aging Family Farm - Estate/Succession Planning for Farmers. Agri Finance 34. April 1992. P. 38-39

6. KLANK, L. Sukcesja gospodarstw rolnych $w$ Polsce, IRWiR PAN, Warszawa 2006. $193 \mathrm{p}$.

7. MISHRA, A. K., EL-OSTA, H.S., AND SHAIK, S. Succession decisions in U.S. family farm businesses. Journal of Agricultural and Resource Economics, 2010, 6: P.285307

8. SIMEONE, M. Paper prepared for presentation at the 94th EAAE Seminar 'From households to firms with Independent legal status: the spectrum of institutional units in the development of European Agriculture', Ashford (UK),9-10 April 2005, p. 1-21 
9. SOBCZYK, M. Statystyka. Wydawnictwo Naukowe PWN, Warszawa 1997. 428p.

\section{Kopsavilkums}

Pēcnācējs, kurš pārṇem uzṇēmumu un nodrošina tā darbības turpināšanu nākamajā paaudzē, ir svarīga ǵimenes uzṇēmuma dạ̦a. Rodas jautājums, vai tie īpašnieki, kuriem ir vai nav pēcnācēju, uzvedas atšķirīgi kapitāla uzkrāšanas ziṇā. Ir mēgónāts noteikt apmēru, līdz kuram pēcnācēja loma sekmē saimnieciska rezultāta sasniegšanu un ieguldījumu apmēru, kas ir kapitāla uzkrāšanas pazīme gimenes lauku saimniecībā.

Laika posmā no 2004. Līdz 2011.g. tika veikti pētījumi, kuros piedalījās 259 Polijas lauksaimnieki vecumā virs 50 gadiem. Aprēksini tika veikti, pamatojoties uz savāktajiem šo lauku saimniecību grāmatvedības datiem. Iegūto rezultātu apjoma novērtējums bija balstīts uz ekonomisko pel̦nu - starpību starp ienākumu no gimenes lauksaimniecības īpašuma un alternatīvajām izmaksām, ietverot attiecīgos ražošanas faktorus. Pēcnācēja loma tika pētīta, pielietojot bināro logistisko regresiju, izmantojot šādus mainīgos: ekonomiskā pel̦na un investīcijas. Rezultāti parādīja, ka lauksaimnieki, kuriem bija pēcnācēji, sasniedza labākus ekonomiskos rezultātus un veica ieguldījumus ar lielāku vērtību. Iespējams, ka mazi ienākumi ir bijuši par iemeslu intereses trūkumam jaunākai paaudzei strādāt lauku saimniecībā. Tomēr, lai apstiprinātu šo pieṇēmumu, ir jāveic pētījums lauksaimnieku vidū, noskaidrojot viṇu bērnu pieñemto lēmumu motīvus.

Izveidotie modelı parādīja, ka būtiskas saistības starp pozitīvas ekonomiskās pel̦nas sasniegšanu un pēcnācēju esamību nav, lai gan statistiski būtisks faktors, kurš palielināja lielāku ieguldījumu iespējamību, bija pēcnācēju esamība. 